\title{
Quayside Mooring System Design of Prelude FLNG for Extreme Environmental Condition
}

\author{
Jin-Woog Cho", Sang-Woong Yun*, Bong-Jae Kim*, Jae-Woong Choi", Booki Kim and Seung-Ho Yang@ \\ "Samsung Heavy Industries Co. Ltd., Korea \\ **echanical Engineering, Ulsan College, Ulsan, Korea
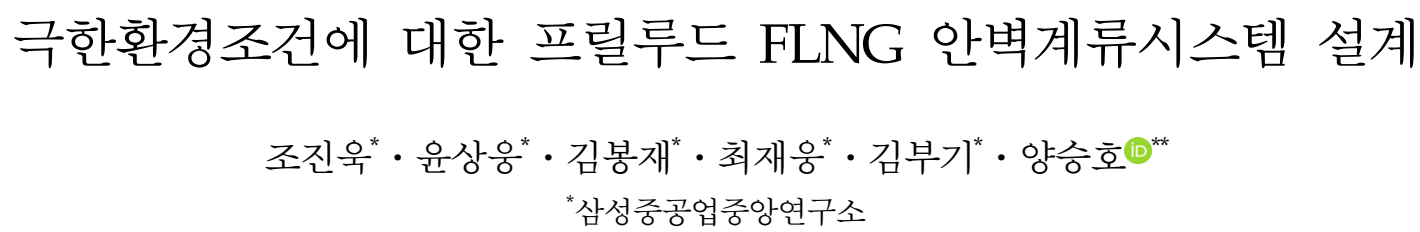

KEY WORDS: Extreme environmental condition 극한환경조건, Prelude FLNG 프릴루드 FLNG, Quayside mooring system design 안벽 계류시스템 설계, Mooring safety 계류안전성

\begin{abstract}
The design and analysis of a quayside mooring system for safe mooring of Prelude FLNG under extreme environmental conditions were carried out. The design of the mooring system considered the yard operation conditions and maximum wind speed during a typhoon. In order to secure the mooring safety of Prelude FLNG under an extreme environment, a special steel structure was designed between the quay and Prelude FLNG to maintain the distance from the quay to a certain extent to avoid a collision with the inclined base. The mooring safety was also ensured by installing additional new parts on the quay. A mooring analysis and mooring safety review were performed with more rigorous modeling considering the nonlinearity of the mooring rope and fender. In order to secure additional safety of the mooring system under extreme environmental conditions, a safety assessment was conducted on the failures of the mooring components proposed in the marine mooring guidelines. Based on the results of the mooring analysis, it was confirmed that the Prelude FLNG can be safely moored even under the extreme conditions of typhoons, and a worst case scenario analysis verified that the mooring system design was robust enough. The proposed mooring analysis and design method will provide a basis for the safe mooring of ultra-large floating offshore structures of similar size in the future.
\end{abstract}

\section{1. 서 론}

글로벌 경기침체에도 불구하고 장기적으로 에너지 수요는 지 속적으로 증가할 것으로 예상된다. 특히, 전문가들 사이에서는 지구온난화에 따른 대안으로 $\mathrm{LNG(Liquefied} \mathrm{natural} \mathrm{gas)와} \mathrm{같은}$ 청정에너지에 대한 수요가 가파르게 상승할 것으로 예상하고 있다. 기술발달에 따른 심해 해상 가스전의 탐사와 개발이 용이 해 지고 있으며, 개발된 에너지의 이송방식이 과거의 파이프라 인과 육상플랜트를 이용한 방식이 아닌 해상에서의 부유식 해 양플랜트를 이용한 새로운 개념의 에너지 이송방식으로 변화되 고 있다(KOSHIPA, 2011; KEIT, 2015; KEEI, 2015).

FLNG(Floating liquefied natural gas)는 해저로부터 채굴된 천 연가스를 해상에서 정제하고 $\mathrm{LNG}$ 로 액화해 저장과 하역을 할 수 있는 부유식 해양플랜트로서 주변환경에 대한 영향이 적고
육상에 대규모 정제를 위한 플랜트를 건설할 필요가 없기 때 문에 최근 들어 오일메이저에서 선호하고 있는 부유식 해양구 조물이다(LNG plant project business group, 2010; KPMG GEI, 2014).

최근에 세일가스 생산량 증가로 인해 추가 FLNG 발주가 지 연되고 있는 상황임에도 불구하고 근래수년에 걸친 FLNG에 대 한 실현가능성 검토(Feasibility study)결과를 토대로 궁극적으로 는 전 세계 $\mathrm{LNG}$ 시장의 수요증가와 맞물려 다수의 FLNG가 발 주될 것으로 기대하고 있다. 프릴루드 FLNG(Fig. 1)는 호주 브 라우즈 유정(Browse basin)의 천연가스 개발을 목표로 프로젝트 가 추진되었으며 규모면에서는 현재까지 건조된 부유식 해양구 조물 중에서 가장 크다. 선체의 길이가 $488 \mathrm{~m}(\mathrm{LBP}$ 기준 $473.6 \mathrm{~m})$, 폭이 $74 \mathrm{~m}$, 깊이가 $43.4 \mathrm{~m}$ 에 이르고, 상부구조물을 포함할 경우 높이가 무려 $110 \mathrm{~m}$ 에 이른다(Table 1). 강재만 26만톤 이상 사용

Received 13 September 2017, revised 5 January 2018, accepted 5 January 2018

Corresponding author Seung-Ho Yang: +82-52-279-3138, shyang@uc.ac.kr ORCID: https://orcid.org/0000-0002-7163-4081

This is an open access article distributed under the terms of the creative commons attribution non-commercial license (http://creativecommons.org/licenses/by-nc/3.0) which permits unrestricted non-commercial use, distribution, and reproduction in any medium, provided the original work is properly cited. 


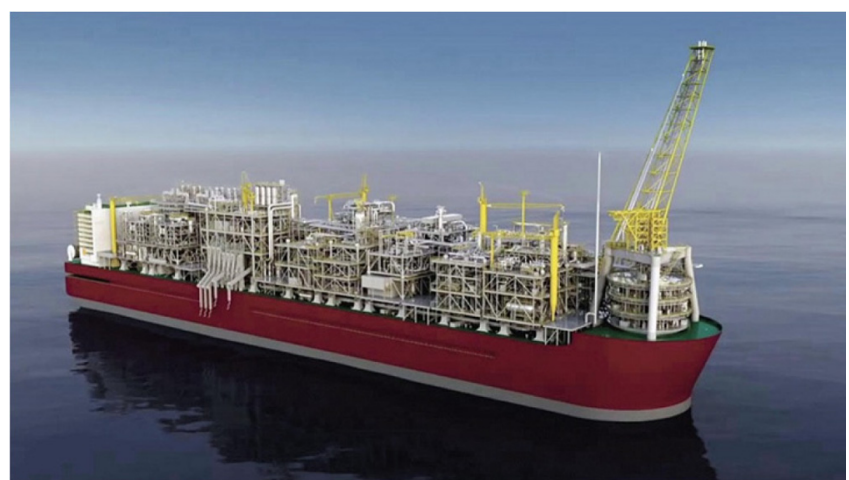

Fig. 1 Prelude FLNG

Table 1 Main particulars of prelude FLNG

\begin{tabular}{ccc}
\hline \hline Items & Dimension & Remarks \\
\hline LBP & $473.6 \mathrm{~m}$ & \\
B & $74.0 \mathrm{~m}$ & \\
$\mathrm{D}$ & $43.4 \mathrm{~m}$ & \\
$\mathrm{~T}$ & $9.8 \mathrm{~m}$ & Quayside \\
Displacement & $316999 \mathrm{MT}$ & Quayside \\
\hline
\end{tabular}

되어 제작되었으며, 만재흘수(Full loaded) 상태에서 배수량은 60 만톤에 이른다(Shell, 2009).

부유식 해양구조물 건조 중, 선체 제작 외에 상부구조물 통 합작업(Topside integration) 및 각종 의장작업을 수행하기 위해 일정기간 안벽접안을 하게 된다. 상부구조물 통합작업과 복잡 한 의장작업을 고려할 때 도크(Dock) 진수 이후 안벽접안 기간 만 최소 2 년 이상 걸리게 된다. 삼성중공업 거제조선소가 위치 해 있는 고현항의 경우, 태풍의 진로에 있기 때문에 반드시 태 풍과 같은 극한환경조건에서도 계류가 가능하도록 계류시스템 설계를 해야 한다. 실 사고사례로 2003년 내습한 태풍 매미로 인해 국내조선소의 안벽접안 후 작업중이던 선박 및 부유식 해 양구조물들이 계류 중 대거 유실되는 사고를 당하여 큰 손실을 입은 바 있다(Na et al., 2004; Park et al., 2011; Yang et al., 2015).

본 연구에서는 이러한 잠재적 위험요소에 따른 극한환경조건 에서의 프릴루드 FLNG의 건조 중 계류안전성을 확보하기 위해 계류시스템을 설계하고 다양한 최악상황 시나리오에 따른 사례 연구(Case study)를 통해 최적으로 설계된 계류시스템을 도출하 고자 하였다.

\section{2. 안벽계류시스템}

안벽에 계류된 선박은 외해에 계류된 선박에 비해 경험하게 되는 환경하중이 상당히 낮을 수 있지만, 부유식 해양구조물의 계류시스템(Mooring system for floating offshore structure)과 달리 상대적으로 계류로프가 짧고, 팽팽한 상태로 유지되므로 해양 구조물의 작은 움직임에도 매우 높은 인장력이 발생할 수 있다. 또한, 계선작업에 따른 계류로프의 초기 인장력 적용과 안벽 및 선체와의 마찰과 마모, 주변 여건에 따른 환경외력 평가방법의 어려움뿐만 아니라 작업 상황에 따른 여러 가지 방해 요소들로 인해 선박과 안벽의 완벽한 연결점을 찾을 수 없는 등 다양한 불완전 요소들이 존재한다. 따라서 효과적인 안벽계류 시스템 설계는 선박 및 안벽과 같은 구조물의 안전뿐 아니라 작업자의 안전을 보장하기 위해서도 필수적이다

프릴루드 FLNG의 계류시스템 설계과정은 선상에서의 계류시 스템 배치와 안벽 접안위치 그리고 작업장 구조물의 간섭 등 현장 작업조건 및 환경조건을 고려한 수치 시뮬레이션을 통해 최종적으로 완성하였다.

\section{1 극한환경조건}

일반적으로 안벽 작업중 겪게 될 극한환경조건을 안벽계류시 스템설계 및 해석의 입력조건으로 사용하게 된다. 프릴루드 FLNG의 경우 계류되어 있는 고현항 내 안벽의 경우, 주변 지형 이 산으로 둘러싸여 있어 외해의 풍속이 상대적으로 크게 감소 되어 실제 안벽에서는 훨씬 작은 풍속값을 나타낸다. 통영, 거 제 기상청 장기 관측자료, 삼성중공업야드 내 안벽부근 건물 옥 상에 설치되어 운용중인 풍속계측시스템의 실계측데이터 등의 자료를 이용하여 100 년 재현주기에 해당하는 설계풍속을 산정 하였다.

\section{2 프릴루드 FLNG 풍하중 면적, 풍하중 계수, 최대풍하중}

풍동 테스트에서 사용된 특정 흘수에서의 프릴루드 FLNG 풍 하중 면적은 Fig. 2에 보이는 바와 같다. 이는 측면도를 기준으 로 할 때, 대형 $\mathrm{LNG}$ 운반선의 네 배 이상 풍하중 면적을 가진 다. 안벽 접안 시 해당 흘수에서 프릴루드 FLNG에 상부구조물 모듈들이 모두 탑재되었을 때를 가정하면, 전면 약 $8,000 \mathrm{~m}^{2}$, 측 면 약 $37,000 \mathrm{~m}^{2}$ 의 풍하중 면적을 가지게 된다.

풍하중 계수는 풍동시험 결과를 이용하였고 방향별 풍하중산 정을 위한 입력조건으로 사용하였다. Fig. 3은 특정 흘수에 해당 하는 풍동시험 모형과 프릴루드 FLNG의 풍하중 계수값이며,
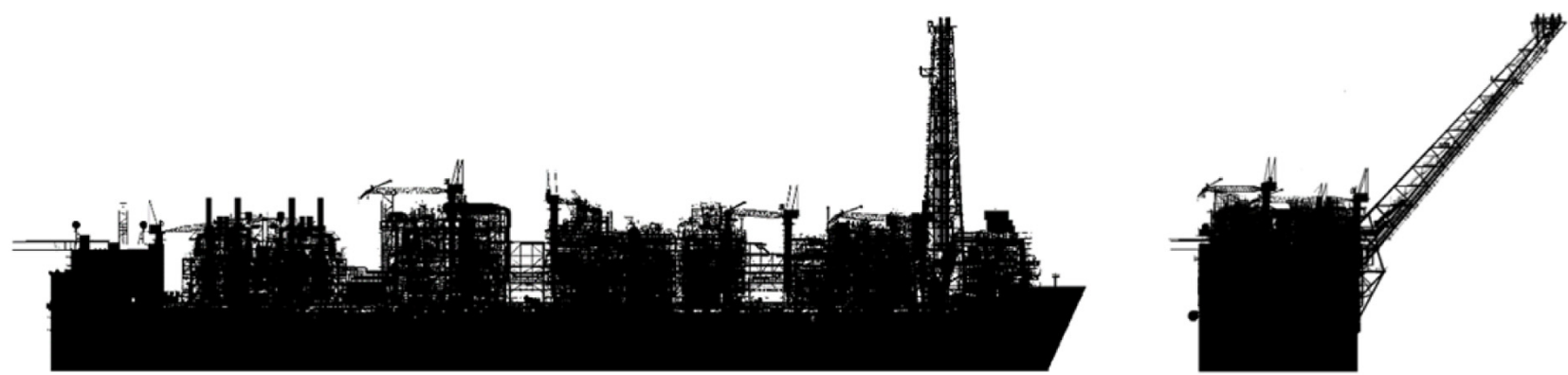

Fig. 2 Prelude FLNG for wind screen calculations(left: side view, right: front view) 

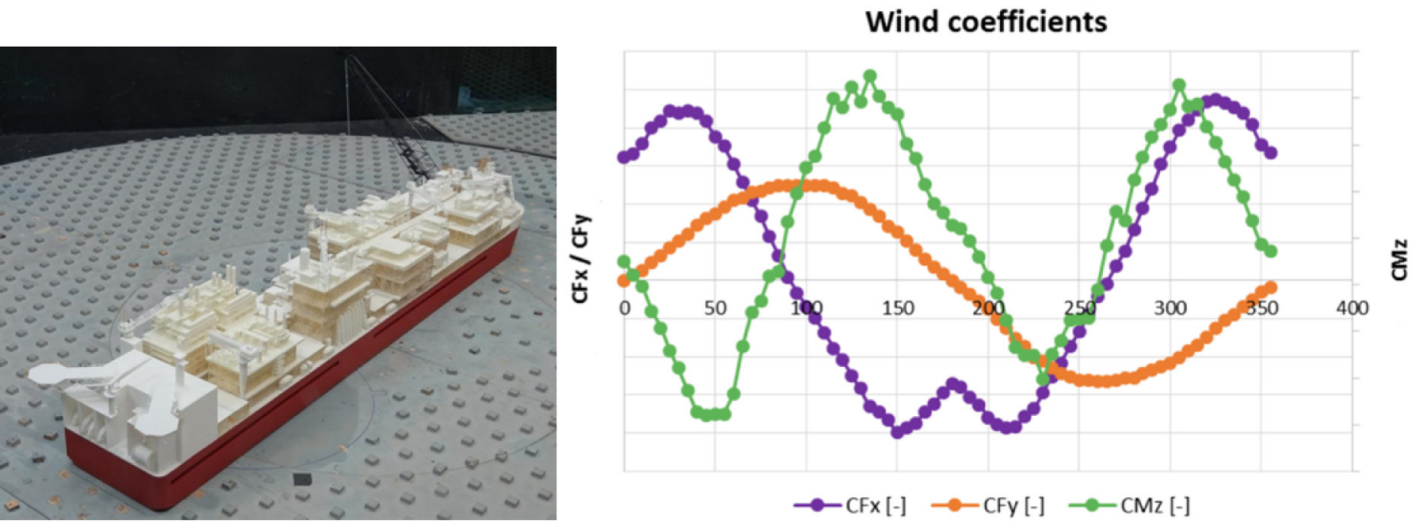

Fig. 3 The model for wind tunnel test and wind coefficients of Prelude FLNG

해석에는 안벽 접안흘수에 가까운 풍동시험 흘수의 풍하중 계 수값을 그대로 사용하고 적용면적을 안벽 접안 조건에 맞게 보 정하여 적용하였다. 본 연구에서는 풍동시험 흘수와 안벽 접안 흘수의 차이가 크지 않아 적용가능한 방법이었으나 만약 흘수 차이가 크다고 하면 해당 흘수 조건에 맞게 풍동시험을 추가로 수행하여 그 결과값을 사용하는 등 보다 현실적인 풍하중 계수 적용 방법을 고려할 필요가 있다.

계류시스템 설계를 위한 최대 풍하중과 최대 모멘트는 아래 식 (1), (2), (3)으로부터 산정될 수 있다.

$$
\begin{aligned}
& F_{X}=\frac{1}{2} \rho_{A} C F_{X} A_{X} V_{W}^{2} \\
& F_{Y}=\frac{1}{2} \rho_{A} C F_{Y} A_{Y} V_{W}^{2} \\
& M_{Z}=\frac{1}{2} \rho_{A} C M_{Z} A_{Y} L_{B P} V_{W}^{2}
\end{aligned}
$$

여기서,

$$
\begin{array}{ll}
\rho_{A} & : \text { 공기밀도 }\left(1.225 \mathrm{~kg} / \mathrm{m}^{3}\right) \\
C F_{X}, C F_{Y}, C M_{Z} & : \text { 축 방향하중 및 모멘트 계수 } \\
A_{X}, A_{Y} & : \text { 축 방향 투영면적 }\left[\mathrm{m}^{2}\right] \\
L_{B P} & : \text { 선체길이 }[\mathrm{m}] \\
V_{W} & : \text { 풍속 }[\mathrm{m} / \mathrm{s}]
\end{array}
$$

산정된 풍하중은 전면과 측면의 면적중심, 즉 전면과 측면의 도 심에 각각 부과하였다.

\section{3 안벽계류시스템 설계}

야드 안벽 건조 작업중 프릴루드 FLNG가 격게될 극한환경하 에서 안전한 계류를 위한 계류시스템 설계는 프릴루드 FLNG 자체의 계류시스템 구성요소와 야드 안벽이 현재 가지고 있는 혹은 추가 설치 가능한 계류시스템 구성요소들을 살펴보는 것 으로부터 시작될 수 있다.

\subsection{1 프릴루드 FLNG 본선 계류구성 요소}

해양(Offshore)에서 본선의 위치 유지를 위해 설치되는 계류시 스템을 제외하고 해양구조물 갑판에 설치되는 대부분의 계류설
비들은 야드에서 안전한 안벽 작업을 수행하기 위해 부착된다 고 볼 수 있다. 이러한 계류설비들은 해양구조물이 초대형화 됨 에 따라 필요 수량의 증가로 공간적 문제뿐만 아니라 구조적, 생산적, 비용적 문제로 확대가 된다. 따라서 초기에 최적 설계 를 통해 이러한 문제를 줄여나가야 할 필요가 있다.

\subsection{2 프릴루드 FLNG 접안안벽 계류구성 요소들}

해양구조물의 초대형화는 설계부터 생산에 이르기까지 극복해 야 할 다양한 문제들을 야기할 뿐만 아니라 접안을 위한 안벽의 길이, 수심 그리고 계선을 위한 비트의 수, 용량, 배치 등에도 개선 을 요구하고 있다. Table 2는 프릴루드 FLNG가 접안하게 될 안벽 의 계류시스템 구성요소들의 개별 설계하중을 나타낸다.

Table 2 Quayside mooring components for Prelude FLNG

\begin{tabular}{ccc}
\hline \hline Items & Capacity & Remarks \\
\hline Bitts & $100 \mathrm{MT}$ & $\begin{array}{c}\text { Horizontal force 100 MT } \\
\text { Vertical force 58 MT } \\
\end{array}$ \\
& $200 \mathrm{MT}$ & $\begin{array}{c}\text { Horizontal force 200 MT } \\
\text { Vertical force 116 MT }\end{array}$ \\
Foam filled fenders & $700 \mathrm{MT}$ & $\begin{array}{c}\text { 4500 } \times 9000 \mathrm{~L}, 60 \% \\
\text { deflection of diameter }\end{array}$ \\
\hline
\end{tabular}

\section{안벽비트 하중테스트(proof load test)}

안벽에 위치해 있는 비트들의 경우, 설치 후 장시간의 사용과 해수에 대한 노출로 인해 지반과 구조물이 초기 설계되었던 하 중을 만족하지 못하고 붕괴되는 상황이 발생할 수 있다. 따라 서, 기설치되어 사용되고 있는 프릴루드 FLNG용 계류 비트들 에 대해 선주, 해사검정보증인(Marine warranty surveyor)과 협의 를 거쳐 선택적으로 하중테스트를 통한 안전성 검증을 수행하 였다. 아래 그림은 하중 테스트를 위해 계측장치를 100 톤, 200 톤 비트에 부착한 것이며, Fig. 4는 비트 하중테스트 절차에 따 른 하중 부과시 비트의 최대 변형량(load-strain)을 나타낸 것이 다. 이때 적용하중은 수평, 수직 방향에 대해 안전작업하중 (SWL, Safe working load)의 1.25 배 값을 사용하였다.

\section{프릴루드 FLNG 접안용 특수 철재구조물}

일반 선박의 접안과 달리 프릴루드 FLNG는 접안을 위한 특 


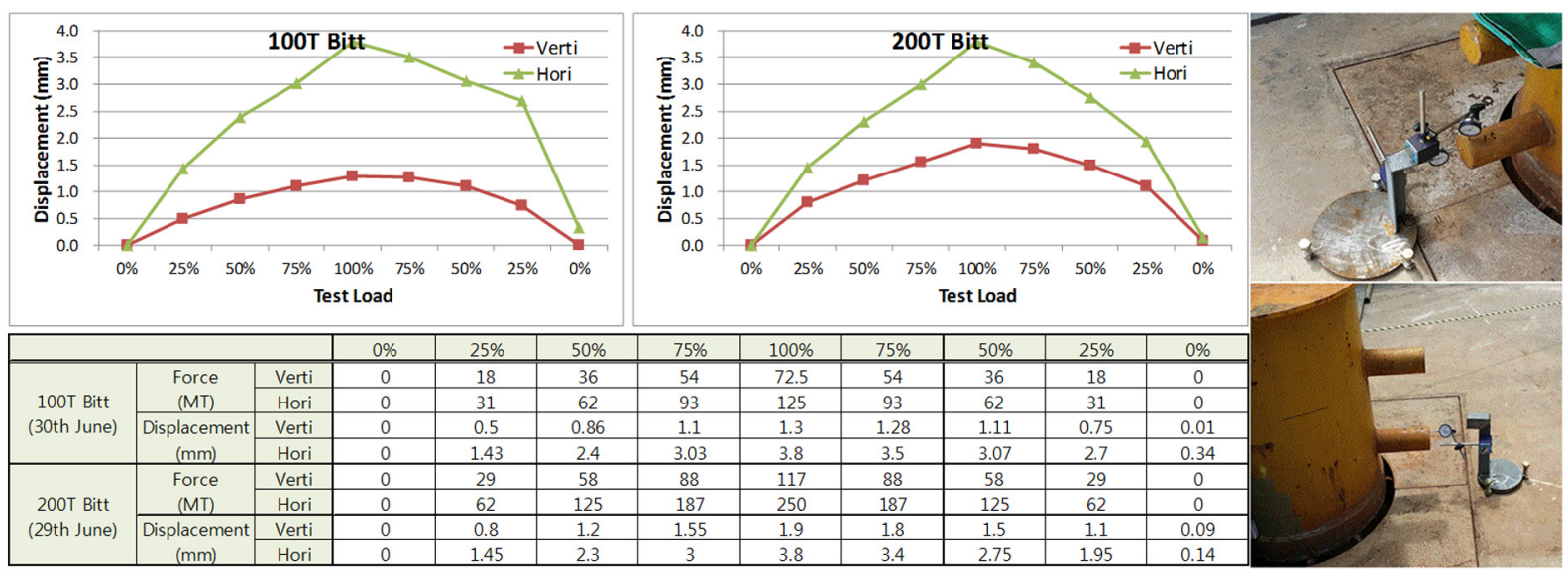

Fig. 4 The results of proof load test for 100 MT and 200 MT bitts
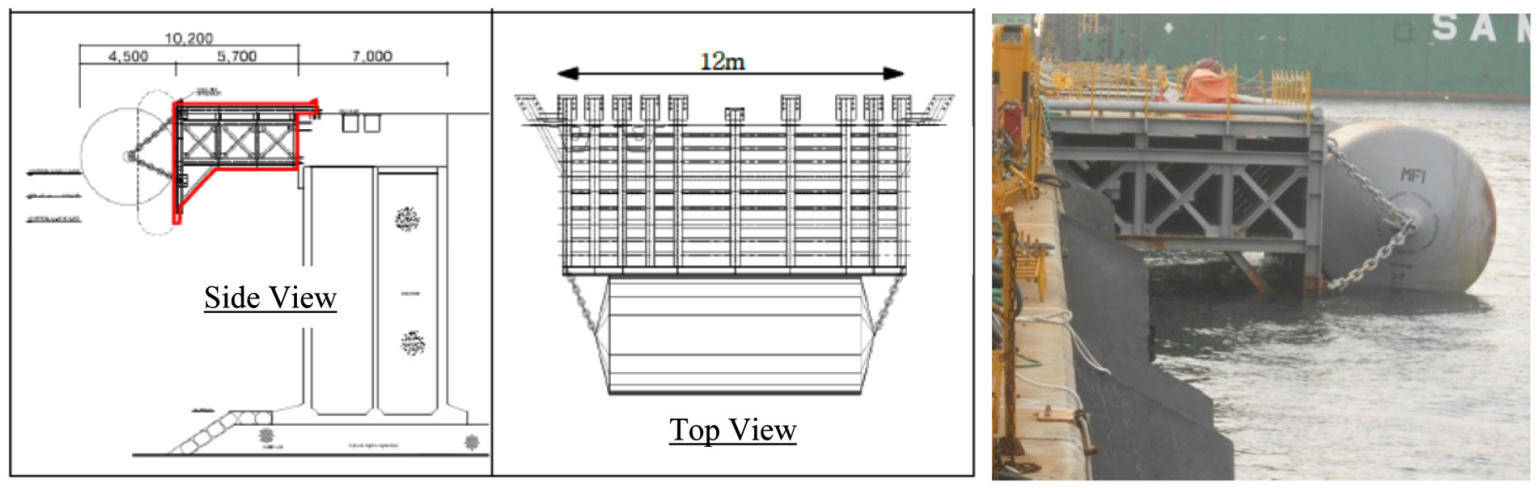

Fig. 5 Steel structure and fender at quay

수 철재구조물이 고안되어 적용되었다(Fig. 5). 특수 철재구조물 의 목적은 접안 안벽의 구조적 형상에 따라 프릴루드 FLNG를 안벽으로부터 충분한 이격거리를 유지함으로써 해저면과 본선 의 바닥면과의 여유공간(Bottom clearance)을 확보하기 위한 것 이다. 바지선(Barge)을 포함한 부유형태의 이격물을 구성할 수 도 있으나 개별 부유구조물들의 파랑 중 상대운동으로 인한 충 돌 등 예상치 못한 위험 상황을 배제하기 위해 고정된 형태의 철재구조물을 고안하여 안벽에 설치하였다. 철재구조물의 경우, 펜더 압착면에 의한 응력변형 등을 고려하여 구조물 자체의 안 전성도 평가하였으나 본 연구논문에서는 추가로 기술하지는 않 았다.

\section{3. 안벽계류를 위한 수치해석적 연구}

본 연구에서는 MOSES(Multi-operational structural engineering simulator, Ver.10.00.01.38) 프로그램을 사용하여 안벽계류해석을 수행하였다. MOSES는 다양한 유형의 해양 플랫폼 및 선박에 대한 정적, 동적 거동해석을 위한 소프트웨어로 해양 구조물의 운송 및 설치 시뮬레이션 및 분석뿐만 아니라 환경외력에 의해 해양구조물에서 발생할 수 있는 응력을 해석할 수 있는 텍스트 기반의 소프트웨어이다.

\section{1 지배방정식 및 해석입력조건}

MOSES는 아래의 방정식 (4)를 이용하여 주파수영역 혹은 시간
영역에서 부유체의 운동 해를 구하게 된다(Bently Systems, 2015).

$$
I \ddot{q}+C \dot{q}+K q=s
$$

여기서,

$I$ : Mass matrix of the body

$C$ : Damping matrix

$K$ : Stiffness matrix

$q$ : Displacement vector

$s$ : Generalized force vector

본 연구에서는 주파수영역 해석법이 적용되었으며 일반적인 안벽계류해석과 마찬가지로 프릴루드 FLNG에 대해서도 준정적 해석법으로 부유체의 변위와 계류로프에 작용하는 힘을 각각 구하였다. 좌표계는 Fig. 6과 같은 우수좌표계를 사용하였으며, 환경외력의 작용방향은 $x$ 축을 기준으로 반시계방향으로 0 도 360 도 방향이 된다.

\section{비선형 계류로프}

계류에 사용되는 로프는 직경, 종류(Synthetic, Polyamide 등) 그리고 연결 지점간의 거리에 따라 작용 하중에 대한 변위량이 달라지므로 가능한 한 동일한 종류, 유사한 길이의 로프들로 구 성하고 배치될 수 있도록 해야 한다. 이럴 경우 통상 계류로프는 로프하중-변형량 특성을 선형으로 가정하여 적용하고 있으나, 


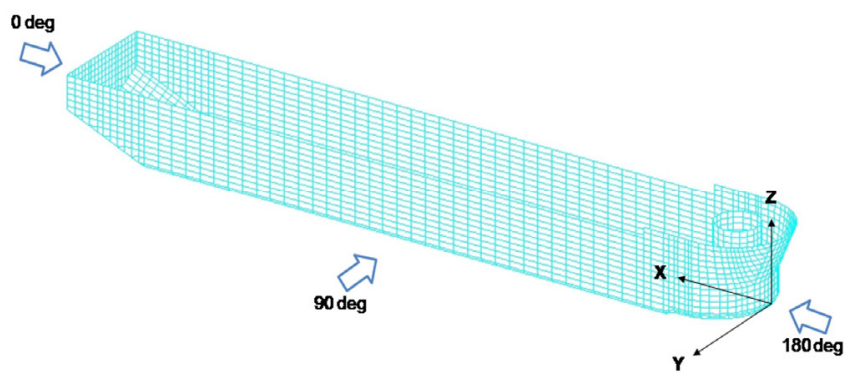

Fig. 6 Coordinates of the Prelude FLNG model and environmental load direction

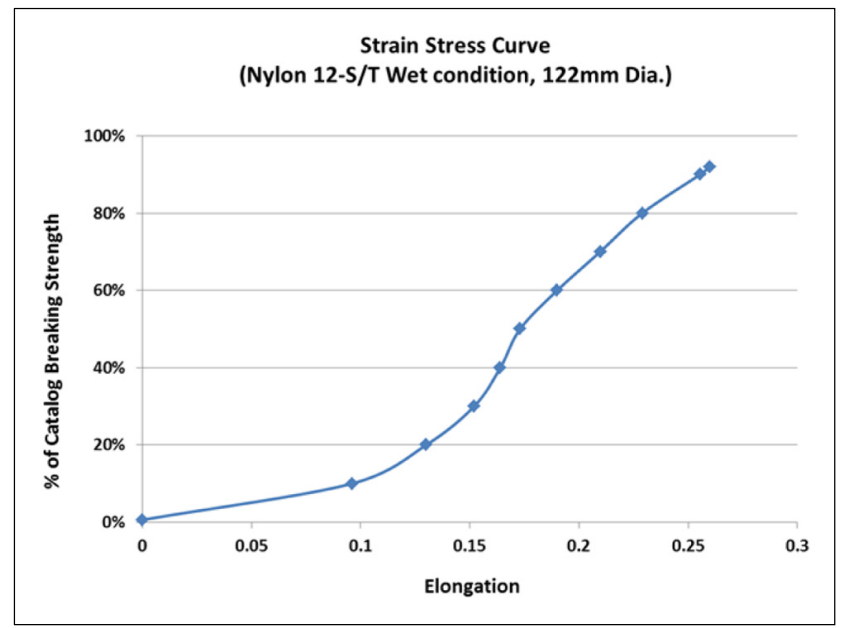

Fig. 7 Mooring rope property

긴 로프와 짧은 로프가 혼재하여 개별 로프간 길이 차이가 크 게 발생하는 계류시스템이 구성되었을 때에는 짧은 로프에 하 중이 집중되는 상황이 제대로 표현될 수 있도록 비선형 로프하 중-변형량 특성을 고려할 필요가 있다. 프릴루드 $\mathrm{FLNG}$ 의 경우 사용되는 계류로프들로 변형률이 큰 나일론 로프를 사용하고, 100 줄 이상 많은 로프들이 적용됨으로 선주, 해사검정보증인과 협의를 통해 Fig. 7 같은 비선형 로프하중-변형량 특성이 반영 될 수 있도록 하였다.

\section{비선형 초대형 계류 펜더}

대형 선박의 안벽 접안 시 본선과 안벽의 직접적인 충돌 방지 를 위해 통상 부유식 형태의 $3300 \mathrm{~mm} \times 6500 \mathrm{~mm}$ 폼필드(Foam filled) 펜더 다수를 선측 수평부에 배치하여 사용한다. 그러나, 프릴루드 FLNG의 경우 정적 환경외력만으로도 기존 폼필드 펜 더의 최대 압축력을 초과하는 상황이 발생함에 따라 $4500 \mathrm{~mm} \times$ $9000 \mathrm{~mm}$ 의 특수 주문제작 펜더를 프릴루드 FLNG 계류용으로 사용하였다. Fig. 8은 주문제작 펜더의 압축하중에 대한 반발력 특성곡선을 나타낸다.

\section{해석 전제 및 가정}

본선 볼라드와 안벽 비트에 연결되는 계류 로프의 초기 인장 력은 균일하게 2톤이 작용하는 것으로 하였다. 보수적 설계를 위해 안벽에 의한 바람의 차폐효과는 무시하였으며, 환경외력 은 모두 동일한 방향에서 입사되는 것으로 가정하였다.
REACTION FORCE vS PERCENT COMPRESSION

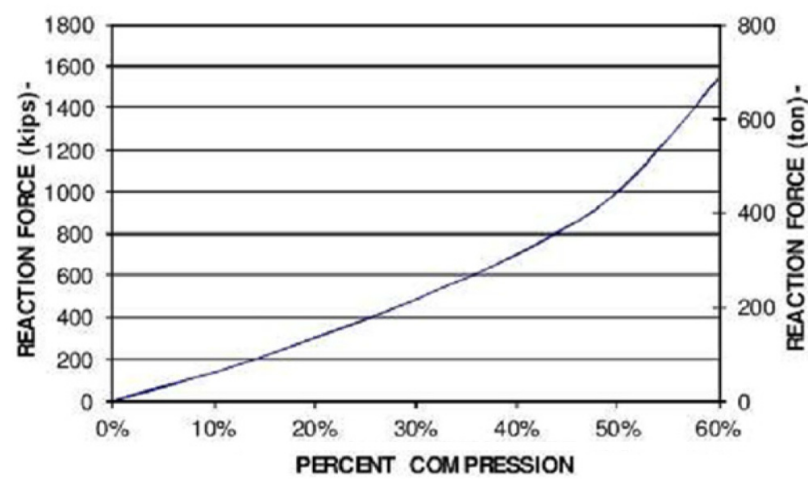

Fig. 8 Load-deflection curve of a fender

\section{2 계류해석 결과}

계류해석을 통해 극한 환경조건에 따른 각 계류로프에 걸리 는 최대하중과 펜더의 반발력, 프릴루드 FLNG의 최대 오프셋 (Offset)을 결과로 얻었다. 특히, 계류로프의 하중분포는 최악상 황 시나리오의 토대가 되는 입력조건으로, 아래와 같은 다섯 가 지의 파단조건을 최악상황에 대한 검증 시나리오로 구성하였다.

(1) 최대하중 로프의 파단(Maximum loaded line failure)

(2) 최대하중 로프 바로 옆 로프의 파단(Neighbor line failure for maximum loaded line)

(3) 최대하중 비트의 붕괴(Maximum loaded bitt failure)

(4) 최대하중 초크의 붕괴(Maximum loaded chock failure)

(5) 최대하중 볼라드의 붕괴(Maximum loaded bollard failure) 최악상황 시나리오는 기본적으로 해양계류 적용지침을 따랐 으며(GL Noble Denton, 2013), 선주, 해사검정보증인과의 긴밀한 협의를 통해 관련 시나리오에 대해 확정짓는 과정을 거쳤다.

\section{계류로프하중과 계류안전성 검증}

거제 고현항 극한환경조건에서 프릴루드 $\mathrm{FLNG}$ 에 대한 안벽 계류해석이 수행되었고, 그 결과 안전한 계류를 위해 총 132 개 의 계류로프와 15 개의 펜더가 소요되었다. Fig. 9는 해석 프로그 램에서 도시된 안벽계류로프 배치도이다.

또한, 계류해석결과를 바탕으로 계류구성요소들이 각각 손상 되는 최악상황 시나리오를 가정하고 이에 따른 프릴루드 FLNG 계류안전성 검증결과를 Table 3 에 요약하였다. Table 3은 계류구 성요소들이 손상받지 않은 조건(Intact)과 최대하중을 받는 계류 로프의 파단조건(Max. 1 line failure), 최대하중을 받는 로프 바 로 옆 로프의 파단조건(Neighbor line failure of Max. line), 최대 하중을 받는 비트의 붕괴조건(Max. loaded bitt failure), 최대하중

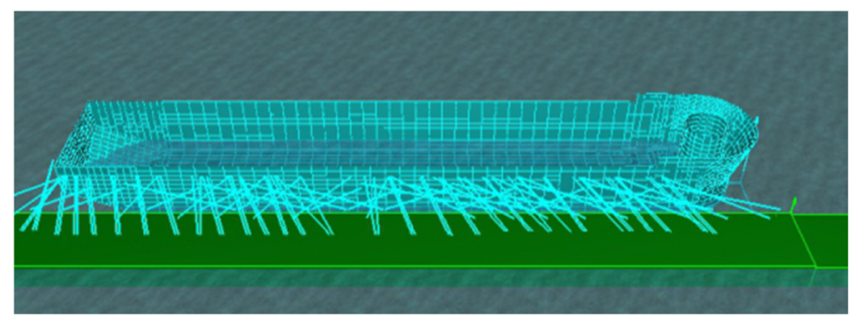

Fig. 9 Quayside mooring arrangement for Prelude FLNG 
Table 3 Mooring analysis results for Prelude FLNG

\begin{tabular}{clcc}
\hline \hline \multicolumn{1}{c}{ Conditions } & Max./SWL & Fender Force \\
\hline \multicolumn{1}{c}{ Intact } & $93.02 \%$ & $94.52 \%$ \\
\hline \multirow{3}{*}{ Damage } & Max. 1 line failure & $92.44 \%$ & $94.49 \%$ \\
& Neighbor line failure of Max. line & $94.34 \%$ & $94.33 \%$ \\
& Max. loaded bitt failure & $95.86 \%$ & $94.31 \%$ \\
& Max. loaded chock failure & $95.38 \%$ & $93.99 \%$ \\
& Max. loaded bollard failure & $94.99 \%$ & $94.17 \%$ \\
\hline
\end{tabular}

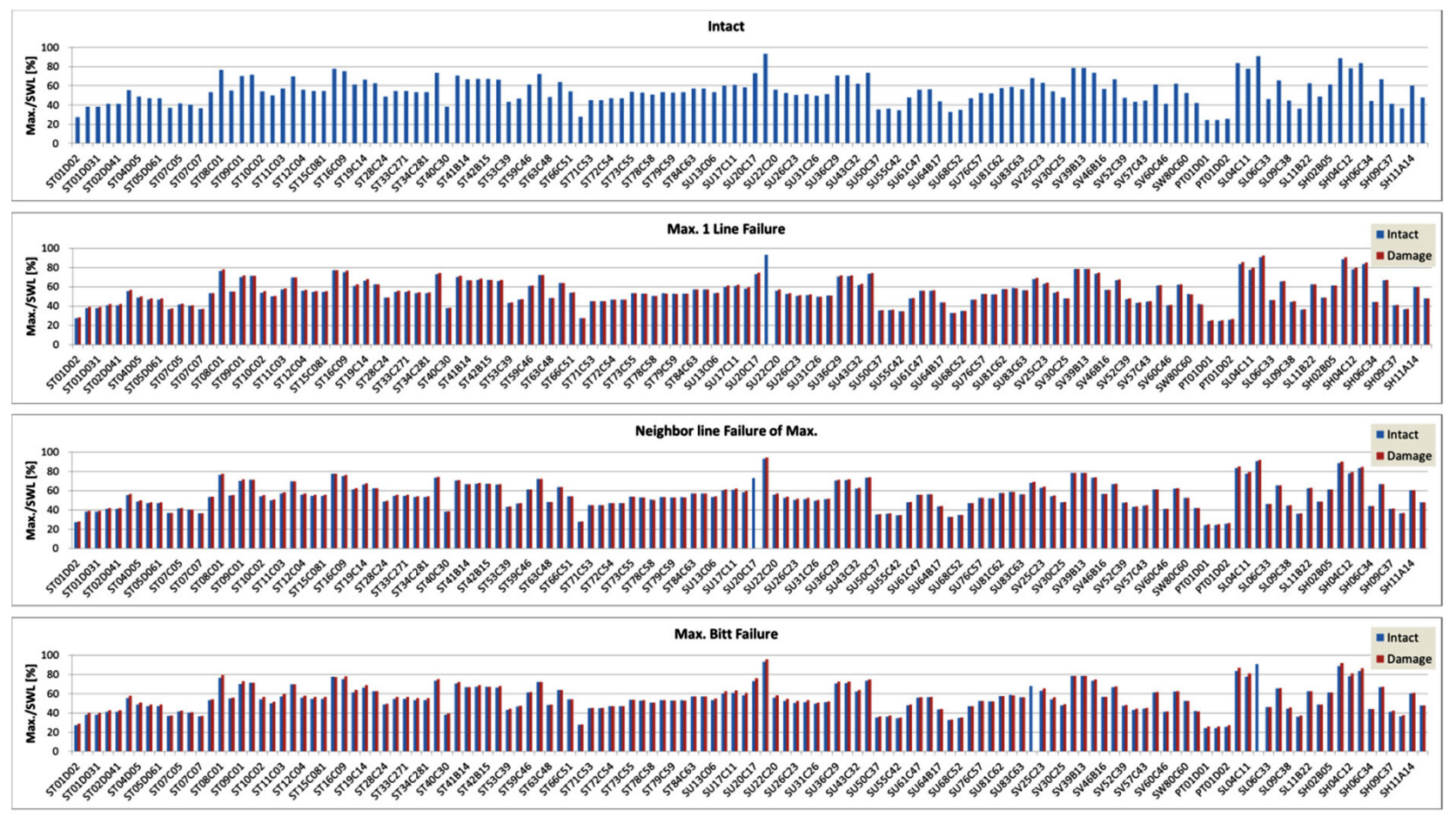

Fig. 10 Mooring analysis results for mooring lines(Intact, Max. 1 line failure, Neighbor line failure of Max. line, Max. loaded bitt failure)

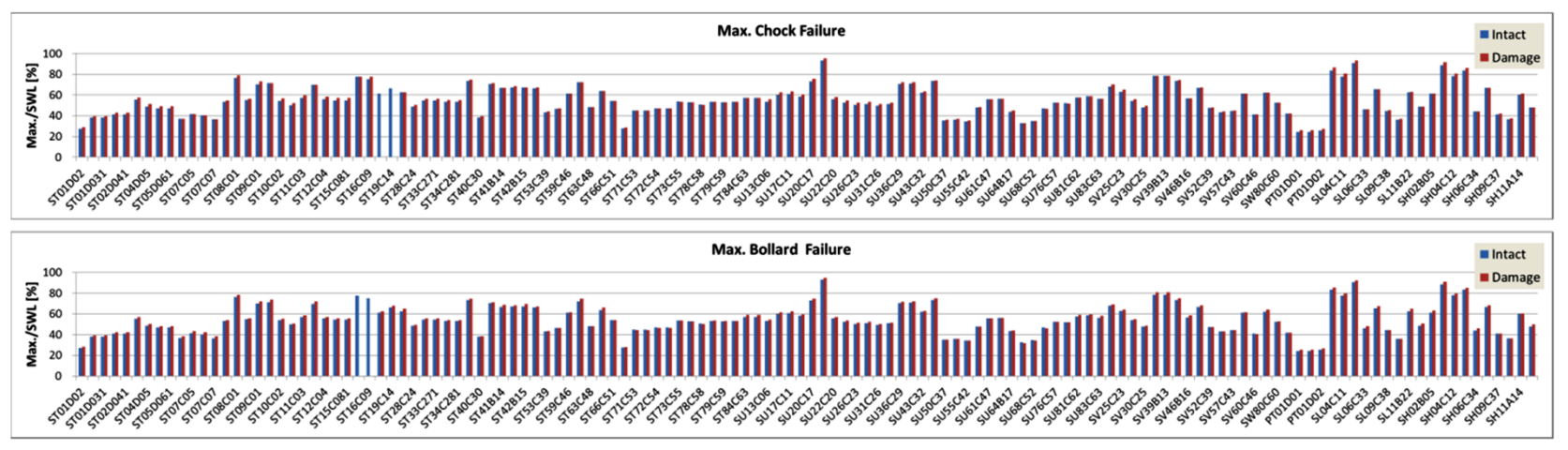

Fig. 11 Mooring analysis results for mooring lines(Max. loaded chock failure, Max. loaded bollard failure)

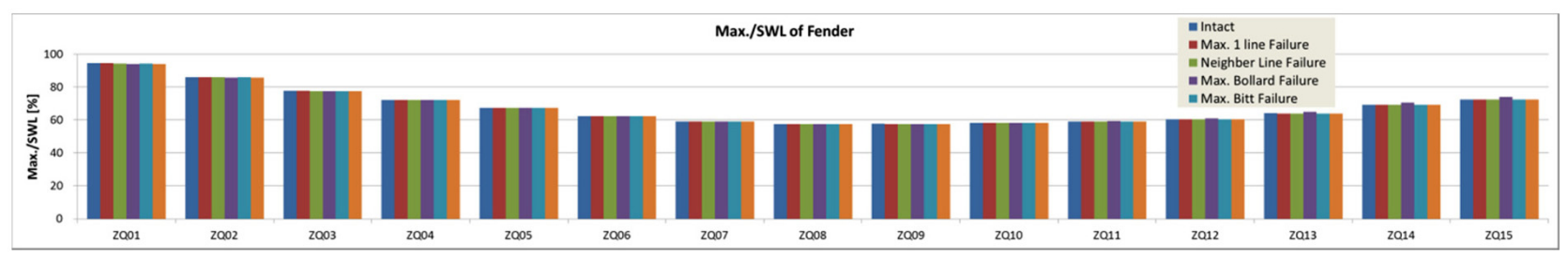

Fig. 12 Mooring analysis results for fender 
을 받는 초크의 붕괴조건(Max. loaded chock failure), 최대하중을 받는 볼라드의 붕괴조건(Max. loaded bollard failure)에 대한 상 황들을 가정하고 이때의 발생되는 최대하중에 대해 안전작업하 중의 비율로 나타낸 것이다. 모든 최악상황 시나리오에 대한 해 석결과에서 로프 최대하중이 안전작업하중을 넘지 않는 결과를 보여주었다. 각각의 최악상황 시나리오에 대한 펜더의 압축하 중 또한 펜더의 설계하중을 넘지 않는 결과를 보여주었다.

각 해석조건에 따른 계류로프에 걸리는 인장력분포와 펜더에 작용하는 압축력분포를 Figs. 10-12에 각각 도시하였다.

일반적으로 최대하중을 받는 계류로프의 파단조건(Max. 1 line)이 가장 흔히 고려될 수 있는 최악상황으로 검토될 수 있 다. 그러나, 최대하중을 받는 로프 바로 옆 로프의 파단조건 (Neighber line of max. failure)은 최대하중 계류로프의 작용하중 을 더욱 높일 수 있기 때문에 이에 대한 검토 또한 타당성 있는 중요한 검토사항으로 볼 수 있다. 비교결과 최대하중을 받는 계 류로프 파단조건의 경우 작업안전하중의 $92.44 \%$ 에 해당하는 계 류로프 최대하중결과를 얻은 반면 최대하중을 받는 로프 바로 옆 로프 파단조건의 경우에는 $94.34 \%$ 로 더 높은 작업안전하중 에 대한 최대하중비율을 얻었다. 따라서, 계류로프 관점에서는 최대하중을 받는 로프 바로 옆 로프의 파단조건을 더 보수적인 최악상황 시나리오로 볼 수 있다.

계류시스템 전체의 안전성 평가에서는 계류로프보다 의장품 류(Fittings; Bollard, Bitt, Chock)의 붕괴가 계류시스템의 안전성 에 더 큰 영향을 미치게 된다. 프릴루드 FLNG와 같은 극초대형 부유식 해양구조물의 경우, 하나의 의장품에 두 개의 계류로프 가 걸리는 상황이 다수 발생하였기 때문에 의장품류의 붕괴 상 황은 두 개의 계류로프가 동시에 끊기게 되는 상황으로 계류시 스템 전체가 순차적으로 붕괴할 수도 있는 위험한 상황에 놓이 게 된다.

\section{4. 결 론}

본 논문에서는 삼성중공업 야드안벽에 계류된 프릴루드 $\mathrm{FLNG}$ 의 안전한 계류시스템 설계를 위하여 극한환경조건에 대 해 프릴루드 FLNG 안벽계류해석을 수행하였다. 프릴루드 FLNG 계류시스템 설계과정과 해석결과들로부터 다음의 결론을 얻을 수 있다.

(1) 본선 볼라드, 초크, 안벽 비트, 철재구조물, 초대형 펜더 등의 개별 계류구성요소들을 이용한 계류시스템 설계를 통해 야드 건조 중 극초대형 해양구조물인 프릴루드 FLNG의 계류안 전성을 확보하였다.

(2) 계류해석 시 비선형 로프, 비선형 펜더 모델을 적용함으로 써 극한환경조건에서 프릴루드 FLNG 계류시스템 구성요소들이 받게 되는 하중을 실제에 더욱 근접하게 모사함으로써 보다 안 전한 계류시스템을 설계할 수 있었다.

(3) 계류시스템 설계 및 해석 과정에 선주사, 해사검정보증인 과의 협의를 통해 다양한 최악상황 시나리오를 산정하여 극한 조건 최악상황에 대비한 강건한 계류시스템 설계 방안을 확보 하였다.
(4) 계류로프와 의장품류가 1 대 1 대응관계일 때는 최대하중 이 걸리는 계류로프의 파단뿐만 아니라 계류로프의 이웃한 로 프의 파단을 최악상황 시나리오로 검토해야 하며, 극초대형 부 유식 해양구조물의 계류시스템과 같은 1 대 다 조건일 경우엔 추가적으로 최대하중이 걸리는 의장품류의 붕괴를 가정하여 계 류시스템의 안전성을 검토해야 한다.

(5) 본 연구결과는 향후에 있을 보다 더 큰 규모의 극초대형 부유식 해양구조물 계류시스템 설계 및 해석을 위한 기초자료 로 사용가능할 것으로 평가되며 유사 대형 해양 프로젝트 수행 을 위한 기본토대가 될 것으로 사료된다.

\section{References}

Bently Systems,2015.Reference Manual for MOSES,Bently Systems. GL Noble Denton, 2013. Technical Policy Board Guidelines for Moorings, GL noble denton 0032/ND. GL Noble Denton.

Korea Offshore and Shipbuilding Association(KOSHIPA), 2011. Analysis of Competitiveness of Offshore Plant Industry and Development of Short-and Long-term Strategy. [Online] Availible at: <http://www.prism.go.kr/> [Accessed January 2017].

Korea Evaluation Instutute of Industrial Technology(KEIT), 2015. The Status and Prospectof Floating OffshorePower Plant Technology. [Online] Availible at: <http://www.kosen21.org $>$ [Accessed January 2017].

Korea Energy Economics Instutute(KEEI), 2015. Tasks and Countermeasures of the Domestic Resource Development Offshore Plant Industry. [Online] Availible at: $<$ https://www. keei.re.kr $>$ [Accessed February 2017].

KPMG Global Energy Instutute(KPMG GEI), 2014. Floating LNG: Revolution and Evolution for The Global Industry. [Online] Availible at: <https://home.kpmg.com $>$ [Accessed February 2017].

LNG Plant Project Business Group, 2010. LNG-FPSO PlanningStudy of LNG Plant Project Business Group. [Online] Availible at: $<\mathrm{http}$ ://ngplant.or.kr/> [Accessed February 2017].

Na, J.H., Sim, W.S., Lee, I.H., Moon, J.S., Kim, J.W., Shin, H.S., 2004. FPSO Quay Mooring Analysis in Typhoon Condition. Proceedings of the Annual Autumn Meeting, Sancheong Korea.

Park, M.K., Cho, J.W., Chung, J.H., 2011. Quay Mooring Analysis for a Drillship in Typhoon Conditions. Journal of the Society of Naval Architects of Korea, Special Issue, 70-74.

Shell Development (Australia) Proprietary Limited, 2009. Prelude Floating LNG Project Environmental Impact Statement. [Online] Availible at: <http://www.shell.com.au/> [Accessed September 2016].

Yang, S.H., Cho, J.W., Kim, H.J., Kim, B.K., 2015. Study on the Mooring Stability of Floating Dock with Ultra Large Offshore Structure. Journal of the Society of Naval Architects of Korea, 52(6), 509-519. 